\title{
PENGARUH PROFITABILITAS, LIKUIDITAS DAN LEVERAGE TERHADAP NILAI PERUSAHAAN DENGAN KEBIJAKAN DIVIDEN SEBAGAI VARIABEL MODERASI
}

\author{
Mei Diah Putri Anggraeni ${ }^{1}$ \\ *Universitas Islam Negeri Maulana Malik Ibrahim \\ *meydia9887@gmail.com ${ }^{1}$ \\ Muhammad Sulhan' \\ *Universitas Islam Negeri Maulana Malik Ibrahim \\ *sulhan100@gmail.com²
}

\begin{abstract}
The purpose of this study is to determine the effect of profitability, liquidity, leverage on firm value and determine the effect of dividend policy in moderating the relationship of the effect of profitability, liquidity, leverage on firm value. This research is a quantitative research. The population is 154 manufacturing companies listed on the Stock Exchange in 2016-2018. The sampling method uses a purposive sampling method and a sample of 39 companies is produced. Analysis using multiple linear regression and MRA (Moderated Regression Analysis) using SPSS software version 24. The results showed that: 1) Profitability and leverage have a significant positive effect on firm value, while liquidity has no effect on firm value, 2) Dividend policy is able to moderate relationship between the effect of profitability on firm value, 3) Dividend policy is not able to moderate the relationship of the influence of liquidity on company value, 4) Dividend policy is able to moderate the relationship of the influence of leverage on firm value.
\end{abstract}

Keywords: Profitability, Liquidity, Leverage, Firm Value, Dividend Policy 


\section{PENDAHULUAN}

Dalam era modern saat ini, bisnis mengalami pertumbuhan yang sangat pesat salah satunya didukung oleh perkembangan teknologi. Hal tersebut berdampak pada perekonomian Indonesia, yang mana dibuktikan dengan terus naiknya angka pertumbuhan ekonomi dari tahun ke tahun. Pada tahun 2016 sebesar 5,03\% kemudian 2017 naik menjadi 5,07 dan pada tahun 2018 mencapai $5,17 \%$ [1]. Salah satu penyumbang serta pendorong utama pertumbuhan ekonomi Indonesia yaitu sektor industri manufaktur yang mana sektor ini berkontribusi pada kegiatan ekspor hingga mencapai angka $79,91 \%$ [2]. Hal tersebut salah satunya didukung oleh banyaknya para investor yang mau mengembangkan sektor manufaktur. Banyaknya investor dikarenakan sektor manufaktur adalah industri pengolahan yang hasil produksinya merupakan produk penting yang dibutuhkan masyarakat seperti makanan dan minuman, obat-obatan, tekstil, otomotif, semen dan lainnya yang tidak terlepas dalam kegiatan sehari-hari sehingga umumnya memiliki prospek yang bagus. Sektor manufaktur di Indonesia dapat meyakinkan para investor untuk menanamkan modalnya juga karena banyaknya potensi seperti tersedianya pasar yang besar dan juga bahan baku yang melimpah [3].

Para investor tersebut dalam menanamkan modalnya tidak langsung memilih perusahaan mana yang akan dituju, akan tetapi menganalisis terlebih dahulu luar dan dalam untuk memastikan apakah dapat memberikan imbal balik yang positif. Hal tersebut dapat dilihat dari nilai perusahaan itu sendiri. Manajer suatu perusahaan harus bisa mengelola secara tepat untuk menghasilkan nilai perusahaan yang tinggi sehingga akan banyak orang yang berminat untuk investasi. Hal penting dalam meningkatkan nilai perusahaan yaitu kinerja keuangan yang bagus karena pengelolaan dananya dilakukan dengan tepat. Kinerja keuangan dapat diperoleh melalui informasi rasio-rasio keuangan dalam laporan keuangan perusahaan (Sari \& Baskara, 2019:14). Berdasarkan studi empiris, analisis kinerja menggunakan rasio keuangan yang dapat mempengaruhi nilai perusahaan antara lain yaitu profitabilitas, likuiditas, leverage. Profitabilitas mempunyai hubungan dengan nilai perusahaan karena semakin banyak keuntungan yang dihasilkan dari aset yang dimilikinya maka para pemegang saham atau investor tertarik karena prospek perusahaan dalam menghasilkan keuntungan juga banyak sehingga nanti return yang akan didapatkannya juga tinggi sehingga akan banyak permintaan saham yang membuat harganya naik yang mencerminkan nilai perusahaan yang tinggi (Yanti \& Abundanti, 2019:5634). Hal ini didukung oleh penelitian oleh Chen \& Chen (2011), Safitri et al. (2014), Astutik (2017), Putri \& Ukhriyawati (2016), Awulle et al. (2018) yang mengatakan bahwa profitabilitas berpengaruh terhadap nilai perusahaan. Tetapi berbeda dengan hasil Pramesti (2015) dan Sitepu \& Wibisono (2015) yang menunjukkan hasil bahwa profitabilitas tidak berpengaruh terhadap nilai perusahaan.

Kemudian likuiditas juga berhubungan karena menunjukkan bagaimana aset yang dimilikinya untuk mendanai kegiatan operasionalnya, jika likuiditas semakin tinggi mengartikan bahwa kinerjanya bagus karena perusahaan mampu membayar utang jangka 
pendeknya menggunakan hartanya yang berarti aset perusahaan mudah dicairkan dan tidak ada yang menganggur yang malah menambah biaya perawatan sehingga dapat menambah kepercayaan investor bahwa perusahaan juga mampu membayar dividen. Dengan begitu maka nilai perusahaan pun juga akan meningkat (Sudiani \& Darmayanti, 2016:4548). Hal ini didukung oleh Putra \& Lestari (2016) yang mengatakan bahwa likuiditas berpengaruh positif terhadap nilai perusahaan. Sedangkan Wulandari (2013) dan Lumoly et al. (2018) yang hasilnya CR tidak berpengaruh terhadap nilai perusahaan.

Lalu ada juga leverage yang menunjukkan bagaimana kemampuan perusahaan dalam memenuhi kewajibannya, jika nilainya kecil berarti semakin baik dalam pemenuhan kewajiban, dan sebaliknya jika nilai leverage nya tinggi. Nilai leverage yang tinggi akan menyebabkan penurunan nilai perusahaan karena mereka tidak mampu membayarkan kewajibannya apalagi untuk memakmurkan pemegang sahamnya (Mery et al., 2017:2003). Akan tetapi menurut Febrianti (2012:146) semakin banyak hutang dapat meningkatkan nilai perusahaan karena biaya bunga hutang dapat mengurangi pembayaran pajak. Akan tetapi jika penggunaan hutang tersebut digunakan hanya untuk investasi yang tidak menguntungkan maka akan timbul risiko financial distress. Penelitian oleh Adetunji et al. (2016), Yanti \& Abundanti (2019), dan Febrianti (2012) menunjukkan hasil bahwa leverage berpengaruh positif terhadap nilai perusahaan yang artinya jika leverage naik maka nilai perusahaan juga akan naik. Berbeda dengan Sari \& Baskara (2019) dan Ferina et al.
(2015) yang mengatakan bahwa leverage tidak berpengaruh terhadap nilai perusahaan.

Saat akan membeli saham seorang calon investor akan menganalisis terlebih dahulu prospek perusahaan, apakah layak atau tidak untuk dijadikan objek investasi. Seorang Investor dalam menanamkan modalnya pasti ingin mendapatkan imbal balik yang menguntungkan dari perusahaan. Imbal balik dari suatu investasi yaitu berupa dividen (Rodoni \& Ali, 2014:115). Para investor menyukai pembayaran dividen yang stabil, maka dari itu perusahaan harus mempertahankan kinerja keuangannya untuk pembayaran dividen yang stabil. Apabila profitabilitas, likuiditas dan leverage perusahaan bagus maka pembayaran dividen akan stabil karena perusahaan mempunyai kondisi keuangan yang menguntungkan (Sudana, 2011:197). Kebijakan dividen pada penelitian ini merupakan variabel moderasi, yang dapat memperkuat maupun memperlemah hubungan profitabilitas, likuiditas dan leverage dengan nilai perusahaan. Penelitian mengenai hal ini telah dilakukan oleh Mery et al. (2017) yang menunjukkan hasil bahwa kebijakan dividen mampu memoderasi hubungan profitabilitas dan likuiditas dengan nilai perusahaan, dan kebijakan dividen tidak mampu memoderasi hubungan leverage dengan nilai perusahaan. Penelitian lainnya yaitu oleh Lestari (2017) yang menyebutkan hasil bahwa kebijakan dividen mampu memoderasi hubungan profitabilitas, likuiditas dan leverage dengan nilai perusahaan.

Berdasarkan fenomena dan isu yang telah dijelaskan dan dari hasil penelitian terdahulu terdapat beberapa variabel yang mempengaruhi nilai perusahaan memiliki 
hasil yang tidak konsisten, bahkan bertentangan dengan hasil penelitian yang satu dengan lainnya. Ketidakkonsistensian dari hasil penelitian-penelitian terdahulu merupakan alasan peneliti untuk mengangkat topik ini untuk diteliti kembali. Perbedaan penelitian ini dengan penelitian sebelumnya yaitu penelitian ini menggunakan variabel PBV untuk nilai perusahaan, ROA untuk profitabilitas, CR untuk likuiditas dan DER untuk leverage dengan variabel moderasi kebijakan dividen serta objek penelitian dan tahun yang berbeda, sehingga tujuan dari penelitian ini yaitu untuk mengetahui pengaruh profitabilitas, likuiditas, leverage terhadap nilai perusahaan dengan kebijakan dividen sebagai variabel moderasi pada perusahaan manufaktur tahun 2016-2018.

\section{KAJIAN PUSTAKA DAN PENGEMBANGAN HIPOTESIS}

A. Pengaruh Profitabilitas, Likuiditas dan Leverage Terhadap Nilai Perusahaan

Profitabilitas merupakan rasio yang digunakan untuk mengukur seberapa besar kemampuan suatu perusahaan dalam menghasilkan keuntungan dengan menggunakan sumber daya yang dimilikinya seperti aktiva, modal dan juga penjualannya. Jika rasio ini semakin tinggi maka dapat diartikan bahwa perusahaan semakin efektif dan efisien dalam menghasilkan laba dengan memanfaatkan sumber dayanya (Sudana, 2011:25). Pada penelitian ini profitabilitas diaproksikan oleh Return on Asset (ROA) yang merupakan gambaran kemampuan perusahaan dalam menghasilkan laba dengan menggunakan aset yang dimilikinya, jika semakin besar maka semakin baik pengelolaan asetnya (Murhadi, 2013:65).
Apabila rasio profitabilitas ini semakin naik maka menandakan bahwa laba semakin bertambah yang akhirnya semakin dapat memakmurkan pemegang sahamnya.

Signaling theory menyebutkan bahwa tingkat profitabilitas yang tinggi menunjukkan prospek perusahaan yang bagus sehingga akan mendapatkan respon yang positif dari investor yang dapat meningkatkan nilai perusahaan. Perusahaan seperti ini dapat menarik minat investor untuk membeli sahamnya, dengan begitu permintaan akan bertambah yang nantinya dapat meningkatkan harga saham yang artinya nilai perusahaan juga naik (Febrianti, 2012:145). Hal ini didukung oleh penelitian Chen \& Chen (2011), Safitri et al. (2014), Astutik (2017), Putri \& Ukhriyawati (2016) dan juga Awulle et al. (2018) yang menunjukkan bahwa profitabilitas berpengaruh terhadap nilai perusahaan.

Berdasarkan uraian di atas maka dapat dirumuskan hipotesis $\mathrm{H}_{1.1}$ penelitian ini yaitu:

$\mathrm{H}_{1.1}$ : Profitabilitas berpengaruh signifikan terhadap nilai perusahaan.

Likuiditas merupakan rasio yang menggambarkan bagaimana kemampuan perusahaan dalam memenuhi kewajiban jangka pendeknya yaitu yang berumur tidak lebih dari satu tahun. Apabila likuiditas semakin tinggi maka hal ini menandakan bahwa perusahaan bagus dalam membayar kewajibannya yaitu tepat waktu, dan sebaliknya jika likuiditasnya rendah. Likuiditas yang tinggi juga mengartikan bahwa perusahaan mempunyai aset yang mudah dicairkan untuk memenuhi kewajibannya (Murhadi, 2013:57). Pada 
penelitian ini likuiditas menggunakan Current Ratio (CR) yang membandingkan hutang lancar perusahaan dengan semua aset lancar yang dimilikinya. Semakin besar CR menandakan bahwa semakin baik perusahaan dalam memenuhi kewajiban jangka pendeknya (Sudana, 2011:24). Hal ini menunjukkan bahwa citra perusahaan adalah baik karena dapat membayar hutangnya, sehingga dapat menarik minat para investor untuk membeli saham di perusahaan seperti ini.

Signaling theory mengatakan bahwa perusahaan dengan tingkat likuiditas yang tinggi akan direspon positif oleh pasar karena menunjukkan kinerja keuangan yang bagus dengan mampu memenuhi kewajiban jangka pendeknya yang berarti perusahaan dapat menjaga likuiditasnya (Wulandari, 2013:456). Karena direspon positif oleh pasar maka akan banyak permintaan saham sehingga dapat meningkatkan harga saham yang berdampak pula pada peningkatan nilai perusahaan. Hal ini didukung oleh penelitian Putra \& Lestari (2016) , Sudiani \& Darmayanti (2016), Dunanti et al. (2017) yang menunjukkan hasil bahwa likuiditas berpengaruh terhadap nilai perusahaan.

Berdasarkan uraian di atas maka dapat dirumuskan hipotesis $H_{1.2}$ penelitian ini yaitu :

$\mathrm{H}_{1.2}$ : Likuiditas berpengaruh signifikan terhadap nilai perusahaan.

Leverage merupakan tingkat pendanaan suatu perusahaan yang berasal dari luar yang mana nantinya perusahaan harus menghasilkan lebih banyak keuntungan atas uang yang dipinjam daripada beban bunga yang ditanggung (Harrison $\mathrm{Jr}$ et al., 2011:277). Rasio ini digunakan untuk melihat bagaimana kemampuan perusahaan dalam memenuhi kewajiban jangka pendek maupun jangka panjangnya. Leverage dalam penelitian ini menggunakan Debt to Equity Ratio (DER) yang merupakan merupakan perbandingan antara total hutang dengan total ekuitas. Rasio ini menunjukkan bagaimana perusahaan memenuhi hutangnya dengan menggunakan ekuitas yang dimiliki. Dengan menghitung DER maka akan diketahui juga risiko keuangan perusahaan, kecil atau besar (Rahmawati, 2017:6). DER yang rendah mengindikasikan bahwa kemampuan perusahaan untuk membayar hutangnya dengan menggunakan modal sendiri semakin baik, sedangkan DER yang tinggi mengartikan bahwa hutang semakin banyak yang nantinya bisa menyebabkan financial distress yang mana menyebabkan para investor tidak berminat untuk membeli saham pada perusahaan tersebut dikarenakan mereka beranggapan bahwa perusahaan tidak mampu membayar hutangnya maka mereka juga tidak akan mendapatkan dividen. Di sisi lain menurut (Febrianti, 2012:146) semakin banyak hutang dapat meningkatkan nilai perusahaan karena biaya bunga hutang dapat mengurangi pembayaran pajak. Penelitian oleh Adetunji et al. (2016), Yanti \& Abundanti (2019) menunjukkan hasil bahwa leverage dapat mempengaruhi nilai perusahaan karena besar kecilnya hutang perusahaan dapat mempengaruhi persepsi para investor dalam membeli saham.

Berdasarkan uraian di atas maka dapat dirumuskan hipotesis $H_{1.3}$ penelitian ini yaitu :

$\mathrm{H}_{1.3}$ : Leverage berpengaruh signifikan terhadap nilai perusahaan. 
B. Pengaruh Kebijakan Dividen Sebagai Variabel Moderasi Dalam Hubungan Antara Profitabilitas Terhadap Nilai Perusahaan

Dividen merupakan distribusi oleh suatu perusahaan kepada para pemegang sahamnya yang biasanya didasarkan pada laba yang diperoleh (Harrison $\mathrm{Jr}$ et al., 2011:23). Menurut Rodoni \& Ali (2014:116) kebijakan dividen pada suatu perusahaan merupakan sesuatu yang penting karena kebijakan pembagian dividen (dividend policy) tidak hanya membagikan keuntungan kepada para investor tetapi juga diikuti dengan pertimbangan adanya kesempatan investasi (reinvesment). Perhitungan kebijakan dividen menggunakan Dividend Payout Ratio (DPR). Rasio profitabilitas menunjukkan seberapa besar laba yang diperoleh perusahaan dari penjualannya dan juga dari investasi lainnya dengan memanfaatkan aset yang dimiliki. Semakin banyak laba yang diperoleh perusahaan akan memberikan dampak positif yaitu menarik minat investor untuk membeli saham. Profitabilitas yang tinggi

mengindikasikan bahwa kinerja keuangan perusahaan baik. Investor senang dengan perusahaan yang mempunyai keuntungan besar dan terus meningkat karena mereka beranggapan bahwa jika keuntungannya besar maka imbal balik yang didapatkan investor akan banyak pula (Lestari, 2017:38). Imbal balik dari investasinya yaitu berupa pembayaran dividen, jika laba yang didapatkan perusahaan semakin banyak maka investor menganggap bahwa dividen yang dibayarkan juga akan banyak pula. Hal itulah yang membuat investor tertarik. Apabila banyak yang minat membeli sahamnya maka permintaan akan naik, kemudian harga saham pun bisa naik yang mencerminkan nilai perusahaan yang tinggi. Hal ini didukung oleh penelitian Mery et al. (2017) yang menunjukkan hasil bahwa kebijakan dividen dapat memoderasi hubungan pengaruh profitabilitas terhadap nilai perusahaan.

Berdasarkan uraian di atas maka dapat dirumuskan hipotesis kedua penelitian ini yaitu :

H2 : Kebijakan dividen mampu memoderasi hubungan antara profitabilitas dengan nilai perusahaan.

$\begin{array}{lrrr}\text { C. Pengaruh } & \text { Kebijakan } & \text { Dividen Sebagai } \\ \text { Variabel Moderasi } & \text { Dalam Hubungan } \\ \text { Antara Likuiditas } & \text { Terhadap Nilai } \\ \text { Perusahaan } & & \end{array}$

Likuiditas merupakan kemampuan perusahaan dalam memenuhi kewajiban jangka pendeknya dengan menggunakan aset lancar yang dimilikinya. Semakin tinggi likuiditasnya maka semakin baik perusahaan dalam membayar hutangnya dengan aset lancarnya yang mudah dan cepat dijadikan uang kas. Hal seperti ini direspon baik oleh pasar karena menunjukkan kinerja keuangan yang bagus karena mampu memenuhi kewajibannya tepat waktu (Febrianti, 2012:456). Perusahaan semacam ini lebih disukai investor karena mereka menganggap jika membeli saham di perusahaan tersebut akan mendapatkan keuntungan dengan prospek perusahaan yang baik.

Jika dalam memenuhi kewajiban jangka pendek saja mampu diselesaikan dengan baik maka manajer dalam membuat kebijakan tidak akan bingung lagi. Kebijakan yang dimaksud yaitu kebijakan pembayaran dividen. Perusahaan dengan likuiditas tinggi 
menggambarkan kas yang tersedia banyak sehingga pembayaran dividen pun akan meningkat pula yang nantinya menarik minat investor sehingga meningkatkan permintaan saham yang mencerminkan peningkatakn nilai perusahaan pula (Mery et al., 2017:2000). Hal ini sejalan dengan penelitian oleh Lestari (2017) yang menunjukkan hasil penelitian bahwa kebijakan dividen dapat memperkuat hubungan pengaruh likuiditas terhadap nilai perusahaan.

Berdasarkan uraian di atas maka dapat dirumuskan hipotesis ketiga penelitian ini yaitu :

H3 : Kebijakan dividen mampu memoderasi hubungan antara likuiditas dengan nilai perusahaan.

D. Pengaruh Kebijakan Dividen Sebagai Variabel Moderasi Dalam Hubungan Leverage Terhadap Nilai Perusahaan

Leverage memperlihatkan bagaimana suatu perusahaan dalam menggunakan dan mengelola hutang yang dimiliki dan bagaimana perusahaan membayarkan hutangnya tersebut. Menurut Febrianti (2012:146) semakin banyak hutang dapat meningkatkan nilai perusahaan karena biaya bunga hutang dapat mengurangi pembayaran pajak. Di sisi lain apabila hutang digunakan untuk investasi yang tidak memberikan keuntungan, perusahaan nantinya akan berhadapan dengan risiko financial distress. Akan tetapi jika perusahaan hanya mengandalkan modal sendiri tanpa hutang maka perusahaan tersebut tidak akan cepat berkembang. Penambahan hutang juga dapat memberikan respon yang positif karena investor menganggap bahwa perusahaan mampu menjaga aliran kas di masa depan dengan baik. Dengan respon positif tersebut maka akan banyak permintaan saham yang mengakibatkan harga saham naik yang mencerminkan nilai perusahaan yang naik pula. Investor dalam membeli saham akan mendapatkan imbal balik berupa dividen. Dengan adanya pembayaran dividen yang diinginkan pemegang saham tersebut, maka kesempatan untuk melakukan investasi oleh manajer dengan menggunakan kas menjadi berkurang. Supaya perusahaan mampu menjaga aliran kas di masa yang akan datang, perusahaan perlu meningkatkan penggunaan hutang. Dengan demikian, investor menganggap bahwa perusahaan tersebut memperhatikan kemakmuran para pemegang sahamnya. Hal ini didukung oleh penelitian Martini \& Riharjo (2014) yang mengatakan bahwa kebijakan dividen memperkuat hubungan pengaruh leverage terhadap nilai perusahaan.

Berdasarkan uraian di atas maka dapat dirumuskan hipotesis keempat penelitian ini yaitu :

H4 : Kebijakan dividen mampu memoderasi hubungan antara leverage dengan nilai perusahaan.

\section{METODE PENELITIAN}

Penelitian ini merupakan penelitian kuantitatif. Populasinya adalah 154 perusahaan manufaktur yang terdaftar di BEI tahun 2016-2018. Metode pengambilan sampel menggunakan purposive sampling method dan dihasilkan sampel sebanyak 39 perusahaan. Analisis menggunakan regresi linear berganda dan MRA (Moderated Regression Analysis) dengan menggunakan software SPSS versi 24. 
Varibel profitabilitas diproksikan dengan ROA (Return on Asset) yang mana memperlihatkan seberapa efektif dan efisien perusahaan dalam menghasilkan laba dengan menggunakan asetnya. Rumus perhitungan ROA yaitu (Murhadi, 2013:64) :

$$
R O A=\frac{E A T}{\text { Total asset }}
$$

Likuiditas diukur dengan Current Ratio (CR) dengan membagi aset lancar dengan utang lancar untuk mengetahui kemampuan perusahaan dalam memenuhi kewajiban hutang jangka pendeknya yang akan jatuh tempo dalam waktu satu tahun. Rumus perhitungannya yaitu (Murhadi, 2013:56) :

$$
\text { Current Ratio }=\frac{\text { Current Asset }}{\text { Current Liabilities }}
$$

Leverage dalam penelitian ini menggunakan Debt to Equity (DER) yang memperhitungkan antara hutang dan ekuitas perusahaan, dengan semakin tinggi DER berarti semakin tinggi pula risiko keuangan suatu perusahaan. Rumus untuk menghitungnya yaitu (Murhadi, 2013:62) :

$$
D E R=\frac{\text { Total hutang }}{\text { Total ekuitas }}
$$

Nilai perusahaan yang didefinisikan sebagai nilai pasar yang mana nantinya akan menunjukkan kemakmuran para pemegang sahamnya. Nilai perusahaan akan terlihat dari berapa harga sahamnya. Nilai perusahaan pada penelitian ini diukur dengan PBV yang rumus perhitungannya adalah sebagai berikut (Murhadi, 2013:66) :

$$
P B V=\frac{\text { Harga saham per lembar }}{\text { Nilai buku ekuitas per lembar }}
$$

Sedangkan variabel kebijakan dividen yaitu memperhitungkan berapa porsi dividen yang dibayarkan kepada pemegang saham dihitung menggunakan Dividend Payout Ratio (DPR), jika semakin besar berarti semakin sedikit laba yang ditahan untuk biaya investasi perusahaan. Rumus perhitungannya yaitu (Murhadi, 2013:65) :

$$
\begin{array}{r}
D P R=\frac{\text { Dividend per share }}{\text { earning per share }} \\
=\frac{\text { Dividend }}{\text { Net Income }}
\end{array}
$$

\section{HASIL DAN PEMBAHASAN}

\section{A. Uji Statistik Deskriptif}

Uji statistik digunakan untuk menganalisis data dengan mendeskripsikan data yang telah terkumpul sebagaimana adanya tanpa bermaksud membuat kesimpulan yang berlaku untuk umum atau generalisasi (Sugiyono, 2012:206).

Tabel 1. Statistik Deskriptif

\begin{tabular}{|c|c|c|c|c|}
\hline Variabel & Min & Max & Mean & $\begin{array}{c}\text { Std. } \\
\text { Deviation }\end{array}$ \\
\hline $\begin{array}{c}\text { Nilai } \\
\text { Perusahaan }\end{array}$ & 0,24 & 55,91 & 4,9297 & 10,50126 \\
\hline Profitabilitas & 1,16 & 46,08 & 10,0608 & 9,96742 \\
\hline Likuiditas & 0,66 & 10,84 & 2,7762 & 2,03294 \\
\hline Leverage & 0,11 & 3,73 & 0,8321 & 0,73519 \\
\hline $\begin{array}{c}\text { Kebijakan } \\
\text { Dividen }\end{array}$ & 4,87 & 90,73 & 37,6523 & 24,15962 \\
\hline
\end{tabular}

Sumber : Data diolah (2020)

B. Uji Asumsi Klasik

Uji Normalitas 
Uji normalitas data bertujuan untuk menguji apakah dalam model regresi, variabel-variabel yang digunakan memiliki distribusi normal atau tidak. Uji normalitas data dapat dilihat dengan melihat pola pada kurva penyebaran P Plot, jika data (titik) menyebar di sekitar garis diagonal dan mengikuti arah garis diagonal berarti menunjukkan pola distribusi yang normal sehingga model regresi dapat memenuhi asumsi normalitas (Ghozali, 2012:160).

\section{Grafik 1. Hasil Uji Normalitas}

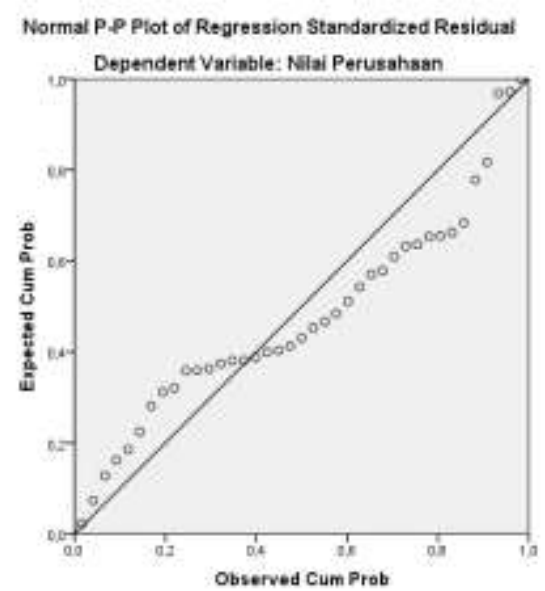

Sumber : Data diolah (2020)

Grafik di atas menunjukkan bahwa data terdistribusi normal dikarenakan titik menyebar di sekitar garis diagonal dan mengikuti arah garis diagonal.

\section{Uji Heteroskedastisitas}

Uji heteroskedastisitas bertujuan menguji apakah dalam regresi terjadi ketidaksamaan varians dari residual satu observasi ke observasi lain. Apabila varians dari residual satu observasi ke observasi yang lain tetap maka disebut homoskedastisitas. Sedangkan, apabila varians dari residual satu observasi ke observasi lain berbeda maka disebut heteroskedastisitas. Model regresi yang baik adalah homoskedastisitas. Untuk mengetahui ada tidaknya heteroskedastisitas dalam satu model regresi linear berganda adalah dengan melihat grafik scatterplot, jika tidak ada pola yang jelas, serta titik-titik menyebar di atas dan di bawah angka pada sumbu Y, maka tidak terjadi heteroskedastisitas (Ghozali, 2012:139).

\section{Grafik 2. Hasil Uji Heteroskedastisitas}

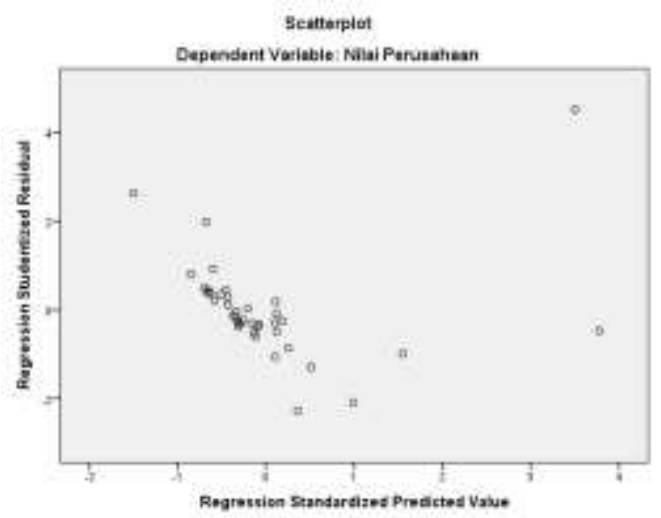

Sumber : Data diolah (2020)

Grafik di atas menunjukkan bahwa pada data penelitian tidak terjadi heteroskedastisitas yang berarti datanya homoskedastisitas dikarenakan titik-titik menyebar di atas dan di bawah angka pada sumbu $\mathrm{Y}$ dan tidak ada pola yang jelas.

\section{Uji Autokorelasi}

Uji autokorelasi bertujuan untuk menguji apakah dalam model regresi linear ada korelasi antara kesalahan pengganggu pada periode $t$ dengan kesalahan pengganggu pada periode t-1 (sebelumnya). Jika terjadi korelasi, maka dinamakan ada problem autokorelasi. Uji ini dapat dilakukan dengan Uji Durbin-Watson dan melihat hasilnya jika nilainya berada diantara dU dan 4-dU maka tidak terjadi autokorelasi (Ghozali, 2012:110). 
Tabel 2. Hasil Uji Autokorelasi

\begin{tabular}{|c|c|}
\hline $\begin{array}{c}\text { Nilai Durbin- } \\
\text { Watson }\end{array}$ & Keterangan \\
\hline 1,898 & Tidak terjadi autokorelasi \\
\hline
\end{tabular}

Sumber : Data diolah (2020)

Tabel di atas menunjukkan bahwa data bebas autokorelasi karena nilai DurbinWatson berada diantara dU dan 4-dU yaitu $1,7215<1,898<2,2785$.

\section{Uji Multikolinearitas}

Uji multikolinearitas bertujuan untuk menguji apakah pada model regresi ditemukan adanya korelasi antar variabel independen. Model regresi yang baik seharusnya tidak terjadi korelasi di antara variabel independen. Uji multikoliearitas dapat dilihat dari nilai tolerance dan Variance Inflation Factor (VIF). Jika nilai tolerance lebih dari 0,10 dan VIF di bawah 10,00 maka bebas multikolinearitas (Ghozali, 2012:105).

Tabel 3. Hasil Uji Multikolinearitas

\begin{tabular}{|c|c|c|c|}
\hline Variabel & Tolerance & VIF & Keterangan \\
\hline $\begin{array}{c}\text { Profitabi- } \\
\text { litas }\end{array}$ & 0,463 & 2,159 & $\begin{array}{c}\text { Tidak terjadi } \\
\text { multikolinearitas }\end{array}$ \\
\hline Likuiditas & 0,748 & 1,336 & $\begin{array}{c}\text { Tidak terjadi } \\
\text { multikolinearitas }\end{array}$ \\
\hline $\begin{array}{c}\text { Leverage } \\
\text { Kebijakan } \\
\text { Dividen }\end{array}$ & 0,730 & 1,371 & $\begin{array}{c}\text { Tidak terjadi } \\
\text { multikolinearitas }\end{array}$ \\
\hline
\end{tabular}

Sumber : Data diolah (2020)

Tabel di atas menunjukkan bahwa data tidak mengalami masalah multikolinearitas karena nilai tolerance semua variabel lebih besar dari 0,10 dan VIF untuk semua variabel lebih kecil dari 10,00.

\section{Uji Regresi Linear Berganda}

Regresi linear berganda ini merupakan uji yang digunakan untuk mengetahui bagaimana pengaruh antara satu atau lebih variabel independen terhadap variabel dependen.

Tabel 4. Hasil Uji Regresi Linear Berganda

\begin{tabular}{|c|c|c|c|}
\hline Variabel & $\begin{array}{c}\text { Koefisien } \\
\text { Regresi }\end{array}$ & $\mathbf{t}$ & Sig. \\
\hline Konstanta & $-4,436$ & $-1,938$ & 0,061 \\
\hline Profitabilitas & 0,888 & 10,779 & 0,000 \\
\hline Likuiditas & $-0,683$ & $-1,470$ & 0,151 \\
\hline $\begin{array}{c}\text { Leverage } \\
\text { Adjusted } R \\
\text { Square }\end{array}$ & 0,787 & 2,175 & 0,036 \\
\hline
\end{tabular}

Variabel dependen : Nilai Perusahaan

Sumber : Data diolah (2020)

Berdasarkan hasil uji regresi pada tabel di atas, maka dapat dituliskan persamaan sebagai berikut :

Nilai Perusahaan $=-4,436+0,888$

Profitabilitas $+(-0,683)$ Likuiditas $+2,790$

Leverage $+\mathrm{e}$

Dari persamaan regresi tersebut maka dapat diinterpretasikan sebagai berikut :

1) Konstanta $(\alpha)$

Nilai konstanta yaitu $-4,436$ yang mengartikan bahwa jika variabel profitabilitas, likuiditas, dan leverage dianggap nol maka nilai perusahaan bernilai $-4,436$

2) Koefisien Regresi Variabel Profitabilitas $\left(\mathrm{X}_{1}\right)$ 
Nilai koefisien regresinya yaitu 0,888 yang menunjukkan bahwa jika variabel profitabilitas naik sebesar $1 \%$ maka nilai perusahaan juga akan naik yaitu sebesar 0,888 .

3) Koefisien Regresi Variabel Likuiditas $\left(\mathrm{X}_{2}\right)$ Nilai koefisien regresinya yaitu $-0,683$ yang menunjukkan bahwa jika variabel likuiditas naik sebesar $1 \%$ maka nilai perusahaan akan turun yaitu sebesar 0,683 .

4) Koefisien Regresi Variabel Leverage $\left(\mathrm{X}_{3}\right)$ Nilai koefisien regresinya yaitu 2,790 yang menunjukkan bahwa jika variabel leverage naik sebesar $1 \%$ maka nilai perusahaan juga akan naik yaitu sebesar 2,790.

\section{Uji Statistik (Uji-t)}

Uji hipotesis atau uji t dilakukan untuk mengetahui pengaruh dari masing-masing variabel independen terhadap variabel dependen. Uji $t$ ini dapat dilihat pada perbandingan $\mathrm{t}$ hitung dan $\mathrm{t}$ tabel dan juga melihat signifikansi masing-masing variabel pada output hasil SPSS dengan significance level $0,05(\alpha=5 \%)$. Jika $\mathrm{t}$ hitung $>\mathrm{t}$ tabel maka variabel independen secara indivual berpengaruh terhadap variabel dependen (hipotesis diterima) dan sebaliknya jika $t$ hitung<t tabel. Apabila nilai probabilitas signifikansinya lebih kecil dari 0,05 (5\%) maka dapat dikatakan bahwa suatu variabel independen berpengaruh signifikan terhadap variabel dependen (Ghozali, 2012:98).

Berdasarkan tabel 4. dapat diketahui bahwa :

1) Uji t terhadap variabel profitabilitas $\left(X_{1}\right)$ didapatkan t hitung sebesar 10,779 dengan signifikansi 0,000. Karena t hitung lebih besar dari $\mathrm{t}$ tabel $(10,779>2,030)$ atau signifikansi t lebih kecil dari 5\% (0,000 < $0,05)$, secara parsial variabel profitabilitas $\left(\mathrm{X}_{1}\right)$ berpengaruh signifikan terhadap variabel nilai perusahaan (Y), maka $\mathrm{H}_{1.1}$ diterima.

2) Uji t terhadap variabel likuiditas $\left(X_{2}\right)$ didapatkan $\mathrm{t}$ hitung sebesar -1,470 dengan signifikansi 0,151. Karena t hitung lebih kecil dari $t$ tabel $(-1,470<2,030)$ atau signifikansi t lebih besar dari 5\% (0,151 > $0,05)$, secara parsial variabel likuiditas $\left(\mathrm{X}_{2}\right)$ tidak berpengaruh terhadap variabel nilai perusahaan (Y), maka $\mathrm{H}_{1.2}$ ditolak.

3) $\mathrm{Uji} t$ terhadap variabel leverage $\left(\mathrm{X}_{3}\right)$ didapatkan t hitung sebesar 2,175 dengan signifikansi 0,036. Karena t hitung lebih besar dari $\mathrm{t}$ tabel $(2,175>2,030)$ atau signifikansi t lebih kecil dari 5\% (0,036 < $0,05)$, secara parsial variabel leverage $\left(\mathrm{X}_{3}\right)$ berpengaruh signifikan terhadap variabel nilai perusahaan (Y), maka $\mathrm{H}_{1.3}$ diterima.

\section{Koefisien Determinasi}

Nilai koefisien determinasi atau adjusted $R$ Square pada model penelitian ini sebesar 0,787 atau 78,7\% yang mengartikan bahwa kemampuan variabel profitabilitas (ROA), likuiditas (CR) dan leverage (DER) dalam mempengaruhi nilai perusahaan adalah sebesar $78,7 \%$ sedangkan sisanya $21,3 \%$ dipengaruhi oleh variabel lainnya yang tidak dimasukkan dalam penelitian ini (Ghozali, 2012:97).

\section{Uji Interaksi / Moderated Regression Analysis (MRA) \\ Moderated Regression Analysis (MRA)} merupakan aplikasi khusus regresi linear berganda yang didalamnya mengandung 
unsur interaksi yang dihasilkan dari perkalian dua atau lebih variabel independen (Ghozali, 2013:219).

\section{Uji Regresi Moderasi Tahap 1}

Pada uji regresi moderasi tahap 1, terdapat dua langkah pengujian yaitu menguji pengaruh $\mathrm{X}_{1}$ dan $\mathrm{Z}$ terhadap $\mathrm{Y}$, kemudian menguji pengaruh $\mathrm{X}_{1}, \mathrm{Z}$ dan $\left(\mathrm{X}_{1} * \mathrm{Z}\right)$ terhadap Y.

Tabel 5. Hasil Regresi Moderasi Tahap 1

\begin{tabular}{|c|c|c|c|}
\hline Variabel & $\begin{array}{l}\text { Std. } \\
\text { Coefficients } \\
\text { Beta }\end{array}$ & $\mathbf{t}$ & Sig. \\
\hline \multicolumn{4}{|l|}{ Langkah 1} \\
\hline Konstanta & & $\begin{array}{l}- \\
2,146\end{array}$ & 0,039 \\
\hline Profitabilitas & 0,857 & 6,559 & 0,000 \\
\hline Kebijakan dividen & $-0,024$ & $\begin{array}{l}- \\
0,181\end{array}$ & 0,857 \\
\hline \multicolumn{4}{|l|}{ Langkah 2} \\
\hline Konstanta & & 1,912 & 0,064 \\
\hline Profitabilitas & $-0,297$ & $\begin{array}{l}- \\
1,066\end{array}$ & 0,294 \\
\hline Kebijakan dividen & $-0,323$ & $\begin{array}{l}- \\
2,585\end{array}$ & 0,014 \\
\hline $\begin{array}{l}\text { Kebijakan } \\
\text { dividen*Profitabilitas }\end{array}$ & 1,424 & 4,483 & 0,000 \\
\hline
\end{tabular}

Variabel dependen : Nilai Perusahaan

Sumber : Data diolah (2020)

Berdasarkan tabel di atas dapat dilihat bahwa beta yang dihasilkan yaitu 1,424 bernilai positif dengan signifikansi $0,000<$ 0,05 yang mengartikan bahwa variabel moderasi kebijakan dividen mampu memperkuat secara signifikan pengaruh profitabilitas $\left(\mathrm{X}_{1}\right)$ terhadap nilai perusahaan (Y), maka dari itu $\mathrm{H}_{2}$ penelitian ini diterima. Dalam hal ini variabel kebijakan dividen merupakan pure moderator karena kebijakan dividen hanya signifikan saat uji langkah kedua atau saat dikalikan dengan variabel $\mathrm{X}$.

\section{Uji Regresi Moderasi Tahap 2}

Pada uji regresi moderasi tahap 2, terdapat dua langkah pengujian yaitu menguji pengaruh $\mathrm{X}_{2}$ dan $\mathrm{Z}$ terhadap $\mathrm{Y}$, kemudian menguji pengaruh $\mathrm{X}_{2}, \mathrm{Z}$ dan $\left(\mathrm{X}_{2} * \mathrm{Z}\right)$ terhadap Y.

Tabel 6. Hasil Regresi Moderasi Tahap 2

\begin{tabular}{|c|c|c|c|}
\hline Variabel & $\begin{array}{l}\text { Std. } \\
\text { Coefficients } \\
\text { Beta }\end{array}$ & $\mathbf{t}$ & Sig. \\
\hline \multicolumn{4}{|l|}{ Langkah 1} \\
\hline Konstanta & & $\begin{array}{l}- \\
0,637\end{array}$ & 0,528 \\
\hline Likuiditas & $-0,216$ & $\begin{array}{l}- \\
1,673\end{array}$ & 0,103 \\
\hline Kebijakan dividen & 0,609 & 4,715 & 0,000 \\
\hline \multicolumn{4}{|l|}{ Langkah 2} \\
\hline Konstanta & & $\begin{array}{l}- \\
2,845\end{array}$ & 0,007 \\
\hline Likuiditas & 0,354 & 1,791 & 0,082 \\
\hline Kebijakan dividen & 1,106 & 6,111 & 0,000 \\
\hline $\begin{array}{l}\text { Kebijakan } \\
\text { dividen*Likuiditas }\end{array}$ & $-0,872$ & $\begin{array}{l}- \\
3,509\end{array}$ & 0,001 \\
\hline
\end{tabular}

Variabel dependen : Nilai Perusahaan

Sumber : Data diolah (2020)

Berdasarkan tabel di atas dapat dilihat bahwa beta yang dihasilkan yaitu $-0,872$ bernilai negatif dengan signifikansi 0,001 < 0,05 yang mengartikan bahwa variabel moderasi kebijakan dividen memperlemah secara signifikan pengaruh likuiditas $\left(\mathrm{X}_{2}\right)$ terhadap nilai perusahaan (Y), maka dari itu $\mathrm{H}_{3}$ penelitian ini ditolak. Dalam hal ini variabel kebijakan dividen merupakan quasi 
moderator karena kebijakan dividen signifikan pada uji langkah 1 dan 2.

\section{Uji Regresi Moderasi Tahap 3}

Pada uji regresi moderasi tahap 3, terdapat dua langkah pengujian yaitu menguji pengaruh $\mathrm{X}_{3}$ dan $\mathrm{Z}$ terhadap $\mathrm{Y}$, kemudian menguji pengaruh $\mathrm{X}_{3}, \mathrm{Z}$ dan $\left(\mathrm{X}_{3} * \mathrm{Z}\right)$ terhadap Y.

Tabel 7. Hasil Regresi Moderasi Tahap 3

\begin{tabular}{|l|l|l|l|}
\hline Variabel & $\begin{array}{l}\text { Std. } \\
\text { Coefficients } \\
\text { Beta }\end{array}$ & t & Sig. \\
\hline Langkah 1 & & - & 0,002 \\
\hline Konstanta & 0,343 & 2,814 & 0,008 \\
\hline Leverage & 0,630 & 5,178 & 0,000 \\
\hline Kebijakan dividen & & & \\
\hline Langkah 2 & & 0,742 & 0,463 \\
\hline Konstanta & $-0,466$ & - & 0,020 \\
\hline Leverage & $-0,005$ & - & 0,976 \\
\hline Kebijakan dividen & & 0,031 & \\
\hline $\begin{array}{l}\text { Kebijakan } \\
\text { dividen*Leverage }\end{array}$ & 1,080 & 4,860 & 0,000 \\
\hline
\end{tabular}

Variabel dependen : Nilai Perusahaan

Sumber : Data diolah (2020)

Berdasarkan tabel di atas dapat dilihat bahwa beta yang dihasilkan yaitu 1,080 bernilai positif dengan signifikansi $0,000<$ 0,05 yang mengartikan bahwa variabel moderasi kebijakan dividen mampu memperkuat secara signifikan pengaruh leverage $\left(\mathrm{X}_{3}\right)$ terhadap nilai perusahaan $(\mathrm{Y})$, maka dari itu $\mathrm{H}_{3}$ penelitian ini diterima. Dalam hal ini variabel kebijakan dividen merupakan quasi moderator karena kebijakan dividen signifikan pada uji langkah pertama dan kedua. 
minat investor untuk menanamkan modal di perusahaan tersebut karena mereka yakin prospek kedepannya menjanjikan. Para investor mempertimbangkan return yang akan mereka dapatkan atas modal yang ditanamkannya dengan melihat profitabilitas perusahaan, maka dari itu investor memilih investasi pada perusahaan dengan profitabilitas yang tinggi.

Sedangkan variabel likuiditas pada penelitian ini diukur menggunakan CR (Current Ratio). Hasil penelitian menunjukkan bahwa likuiditas tidak berpengaruh dan $\mathrm{t}$ hitung yang diperoleh negatif terhadap nilai perusahaan manufaktur tahun 2016-2018. Hal ini dikarenakan jika likuiditas perusahaan semakin tinggi di atas titik optimal justru akan menurunkan nilai perusahaan dikarenakan adanya aset menganggur yang tidak dimanfaatkan atau tidak dikelola oleh manajemen perusahaan. Menurut Fahmi (2011:61) perusahaan dengan CR yang baik maka dianggap sebagai perusahaan yang kinerjanya baik pula. Akan tetapi CR yang terlalu tinggi juga tidak dianggap baik karena hal tersebut mencerminkan adanya masalah seperti banyaknya jumlah persediaan yang dimiliki dibandingkan dengan taksiran tingkat penjualannya sehingga tingkat perputaran persedian menjadi rendah. Jadi CR yang tinggi belum tentu mencerminkan kondisi perusahaan yang sedang baik.

Hasil penelitian ini sejalan dengan Wulandari (2013) dan Lumoly et al. (2018) yang hasilnya CR hubungannya negatif dengan nilai perusahaan, CR tinggi justru menurunkan nilai perusahaan. Likuiditas yang tinggi apabila dilihat dari sudut pandang kreditur perusahaan dalam kondisi ini akan dinilai baik. Tetapi disisi lain apabila dilihat sudut pandang investor dan calon investor justru dinilai perusahaan tidak mempunyai kemampuan untuk memutar modal kerjanya yang dimiliki. Akibatnya yaitu banyak dana yang menganggur, sehingga kemampuan perusahaan dalam memperoleh keuntungan juga rendah, maka dengan kondisi seperti ini membuat minat investor untuk berinvestasi menjadi turun, yang kemudian menurunkan nilai perusahaan karena permintaan saham rendah dan harganya menjadi turun.

Variabel leverage dalam penelitian ini diukur menggunakan DER (Debt to Equity Ratio). Hasil penelitian menunjukkan bahwa leverage berpengaruh signifikan terhadap nilai perusahaan manufaktur tahun 20162018. Hasil ini mengartikan bahwa semakin tinggi leverage maka nilai perusahaan juga akan semakin tinggi. Menurut Murhadi (2013:62) rasio ini memperhitungkan antara hutang dan ekuitas perusahaan, dengan semakin tinggi DER berarti semakin tinggi pula risiko keuangan suatu perusahaan. Menurut Febrianti (2012:146) dengan semakin banyak hutang dapat meningkatkan nilai perusahaan karena biaya bunga hutang dapat mengurangi pembayaran pajak dan juga penggunaan utang akan meningkatkan nilai perusahaan, karena saat kebutuhan hutangnya naik biasanya digunakan untuk pembiayaan perusahaan. Peningkatan nilai tersebut dikaitkan dengan harga saham dan penurunan utang akan menurunkan harga saham. Akan tetapi jika penggunaan hutang tersebut tidak diimbangi dengan hati-hati dan digunakan hanya untuk investasi yang tidak menguntungkan maka akan timbul risiko financial distress atau kebangkrutan. 
Hasil penelitian ini sejalan dengan penelitian oleh Adetunji et al. (2016), dan Yanti \& Abundanti (2019) yang menunjukkan hasil bahwa leverage yang diukur dengan DER berpengaruh terhadap nilai perusahaan. Hasil ini mendukung teori sinyal yang menyatakan bahwa peningkatan leverage memberikan dua macam sinyal, yaitu good news dan bad news. Berdasarkan hasil penelitian dapat diketahui bahwa peningkatan DER dalam hal ini cenderung mengarah kepada good news dikarenakan peningkatan hutang tersebut mencerminkan kemampuan manajemen untuk meningkatkan nilai perusahaan. Para investor dan calon investor menganggap bahwa perusahaan dengan kondisi seperti ini sedang mengalami perkembangan yang pesat sehingga membutuhkan tambahan dana. Perkembangan ini memungkinkan perusahaan untuk melakukan ekspansi, diversifikasi dengan cara membentuk portofolio. Hal ini membuat minat pasar untuk melakukan investasi, sehingga banyak permintaan saham dan membuat harga saham meningkat yang mencerminkan meningkatnya nilai perusahaan.

Pengaruh Profitabilitas terhadap Nilai Perusahaan dengan Dimoderasi Oleh Kebijakan Dividen

Variabel moderasi kebijakan dividen dihitung menggunakan DPR (Dividend Payout Ratio). Hasil penelitian ini menunjukkan bahwa kebijakan dividen mampu secara signifikan memoderasi hubungan pengaruh profitabilitas terhadap nilai perusahaan manufaktur tahun 20162018. Dividend Payout Ratio yang tinggi memperkuat hubungan pengaruh profitabilitas terhadap nilai perusahaan.
Dividend Payout Ratio dapat meningkatkan nilai perusahaan saat profitabilitasnya tinggi dan juga dapat menurunkan nilai perusahaan saat profitabilitas rendah. Hal ini sejalan dengan penelitian oleh Mery et al. (2017) yang menunjukkan hasil bahwa kebijakan dividen yang diukur dengan Dividend Payout Ratio dapat memoderasi pengaruh profitabilitas terhadap nilai perusahaan.

Semakin banyak profit atau laba yang diperoleh perusahaan akan memberikan dampak positif yaitu menarik minat investor untuk membeli saham. Profitabilitas yang tinggi serta kebijakan dividen yang optimal mampu mencerminkan prospek perusahaan yang bagus sehingga dapat menaikkan harga saham serta meningkatkan nilai perusahaan [23] . Investor senang dengan perusahaan yang mempunyai keuntungan besar dan terus meningkat karena mereka beranggapan bahwa jika keuntungannya besar maka imbal balik yang didapatkan investor akan banyak pula. Imbal balik dari investasinya yaitu berupa pembayaran dividen, jika laba yang didapatkan perusahaan semakin banyak maka investor menganggap bahwa dividen yang dibayarkan juga akan banyak pula. Hal itulah yang membuat investor tertarik. Apabila banyak yang minat membeli sahamnya maka permintaan akan naik, kemudian harga saham pun bisa naik yang mencerminkan nilai perusahaan yang tinggi.

Pengaruh Likuiditas terhadap Nilai Perusahaan dengan Dimoderasi Oleh Kebijakan Dividen

Variabel moderasi kebijakan dividen dihitung menggunakan DPR (Dividend Payout Ratio). Hasil penelitian ini menunjukkan bahwa kebijakan dividen tidak mampu memoderasi pengaruh likuiditas 
terhadap nilai perusahaan manufaktur tahun 2016-2018, yang berarti Dividend Payout Ratio tidak dapat meningkatkan nilai perusahaan saat likuiditas tinggi dan Dividend Payout Ratio tidak dapat menurunkan nilai perusahaan saat likuiditas rendah. Hasil penelitian ini bertolak belakang dengan penelitian oleh Mery et al. (2017) yang menunjukkan hasil bahwa kebijakan dividen yang diukur dengan Dividend Payout Ratio mampu memoderasi pengaruh likuiditas terhadap nilai perusahaan.

Semakin tinggi atau rendahnya Dividend Payout Ratio tidak akan mempengaruhi hubungan antara likuiditas dengan nilai perusahaan yang mengartikan bahwa kebijakan dividen tidak menimbulkan reaksi pasar sehingga tidak mempengaruhi kenaikan dan penurunan nilai perusahaan. Hal seperti ini dikarenakan saat likuiditas perusahaan rendah maka besarnya pembayaran dividen juga kecil dibandingkan laba yang diperoleh selama tahun 2016-2018 sehingga tidak berdampak untuk nilai perusahaan [27].

Pengaruh Leverage terhadap Nilai Perusahaan dengan Dimoderasi Oleh Kebijakan Dividen

Variabel moderasi kebijakan dividen dihitung menggunakan DPR (Dividend Payout Ratio). Hasil penelitian ini menunjukkan bahwa kebijakan dividen mampu secara signifikan memoderasi hubungan pengaruh leverage terhadap nilai perusahaan manufaktur tahun 2016-2018. Dividend Payout Ratio yang tinggi memperkuat hubungan pengaruh leverage terhadap nilai perusahaan. Dividend Payout Ratio dapat meningkatkan nilai perusahaan saat leverage perusahaan tinggi dan juga dapat menurunkan nilai perusahaan saat leverage rendah. Hasil penelitian ini sejalan dengan penelitian oleh Martini \& Riharjo (2014). Investor dalam membeli saham akan mendapatkan imbal balik berupa dividen. Dengan adanya pembayaran dividen yang diinginkan pemegang saham tersebut, maka kesempatan untuk melakukan investasi oleh manajer dengan mengguakan kas menjadi berkurang. Supaya perusahaan mampu menjaga aliran kas di masa yang akan datang, perusahaan perlu meningkatkan penggunaan hutang. Menurut Lestari (2017) dengan adanya penambahan hutang oleh perusahaan dapat digunakan untuk mengendalikan aliran kas perusahaan karena perusahaan yang menerbitkan hutang memerlukan pembayaran kembali bunga dan pokok pinjaman yang mengggunakan kas perusahaan sehingga dapat menghindari adanya pemborosan dan investasi yang berlebihan oleh manajer. Hal ini berarti perusahaan mampu menjaga aliran kas perusahaan dan menggunakan sumber daya tersebut dalam kegiatan yang produktif. Dengan demikian, investor menganggap bahwa perusahaan tersebut memperhatikan kemakmuran para pemegang sahamnya. Dengan kondisi seperti ini maka akan menarik investor untuk menanamkan dana pada perusahaan tersebut, kemudian permintaan saham meningkat sehingga harga sahamnya naik yang mana mencerminkan nilai perusahaan yang tinggi.

\section{SIMPULAN}

Berdasarkan hasil analisis pengaruh dari variabel-variabel profitabilitas, likuiditas, leverage terhadap nilai perusahaan dengan kebijakan dividen sebagai variabel moderating pada perusahaan manufaktur 
yang terdaftar di Bursa Efek Indonesia tahun 2016-2018 dapat ditarik kesimpulan yaitu :

1) Variabel profitabilitas yang diproksikan dengan ROA (Return on Asset) berpengaruh positif signifikan terhadap nilai perusahaan, kemudian variabel likuiditas yang diproksikan dengan CR (Current Ratio) tidak berpengaruh terhadap nilai perusahaan, sedangkan variabel leverage yang diproksikan dengan DER (Debt to Equity Ratio) berpengaruh positif signifikan terhadap nilai perusahaan.

2) Kebijakan dividen (DPR) mampu secara signifikan memoderasi hubungan pengaruh profitabilitas terhadap nilai perusahaan. DPR memperkuat hubungan pengaruh profitabilitas terhadap nilai perusahaan.

3) Kebijakan dividen (DPR) tidak mampu secara signifikan memoderasi hubungan pengaruh likuiditas terhadap nilai perusahaan. DPR tidak mampu meningkatkan nilai perusahaan saat likuiditas tinggi dan tidak dapat menurunkan nilai perusahaan saat likuiditas rendah.

4) Kebijakan dividen (DPR) mampu secara signifikan memoderasi hubungan pengaruh leverage terhadap nilai perusahaan. DPR memperkuat hubungan pengaruh leverage terhadap nilai perusahaan.

\section{REFERENSI}

Vincent, "Ekonomi RI Tumbuh 5,17 persen pada 2018, Terbaik Sejak 2014," Diperoleh tanggal 20 Desember 2019,
2019. [Online]. Available: https://www.bps.go.id.

Badan Pusat Statistik, Analisis Komoditas Ekspor Badan Pusat Statistik. BPS RI : CV. Kemsiro Berkarya, 2019.

A. Hartanto, "Menperin Sebut Investasi Sektor Manufaktur Naik Signifikan," Diperoleh tanggal 14 Desember 2019, 2018. .

N. K. P. P. Sari and I. G. K. Baskara, "Pengaruh Leverage, Profitabilitas dan Economic Value Added Terhadap Nilai Perusahaan Pertambangan Di Bursa Efek Jakarta," J. Manaj. dan Kearifan Lokal Indones., vol. 3, no. 1, pp. 12-24, 2019, doi: 10.26805/jmkli.v3i1.39.

P. D. M. Yanti and N. Abundanti, "Pengaruh Profitabilitas, Leverage dan Kebijakan Dividen Terhadap Nilai Perusahaan Properti, Real Estate Dan Konstruksi Bangunan," E-Jurnal Manaj., vol. 8, no. 9, pp. 5632-5651, 2019.

L. Chen and S. Chen, "“ The influence of profitability on firm value with capital structure as the mediator and firm size and industry as moderators, The influence of profitability on firm value with capital structure as the mediator and firm size and industry as moderators," $J$. Invest. Manag. Financ. Innov., vol. 8, no. 3, 2011.

O. N. Safitri, S. R. Handayani, and N. F. Nuzula, "The Influence Of Capital Structure ( A Study in Retail Companies Listed in Indonesia Stock Exchange 2010-2013 period )," J. Adm. Bisnis, vol. 13, no. 2, pp. 1-19, 2014.

D. Astutik, "Pengaruh Aktivitas Rasio Keuangan Terhadap Nilai Perusahaan (Studi Pada Industri Manufaktur," J. STIE Semarang, vol. 9, no. 1, 2017.

R. W. Putri and C. F. Ukhriyawati, "Pengaruh Likuiditas, Leverage dan Profitabilitas Terhadap Nilai Perusahaan Pada Perusahaan Telekomunikasi yang Terdaftar di Bursa Efek Indonesia Tahun 
2012-2014," J. BENING, vol. 3, no. 1, pp. 52-73, 2016.

I. D. Awulle, S. Murni, and C. N. Rondonuwu, "Pengaruh Profitabilitas Likuiditas Solvabilitas dan Kepemilikan Institusional Terhadap Nilai Perusahaan Food And Beverage yang Terdaftar di Bursa Efek Indonesia Periode 20122016," J. EMBA, vol. 6, no. 4, pp. 19081917, 2018.

I. D. Pramesti, "Pengaruh Profitabilitas, Likuiditas, dan Aktivitas Terhadap Price To Book Value (PBV) Pada Perusahaan Tekstil dan Garmen yang Terdaftar Di BEI Periode (2010-2013).," Universitas Muhammadiyah Surakarta, 2015.

N. R. Sitepu and C. H. Wibisono, "Pengaruh Kebijakan Dividen, Kebijakan Leverage, dan Profitabilitas Terhadap Nilai Perusahaan (Perusahaan Manufaktur Yang Terdaftar di BEI Tahun 20092013).," 2015.

N. K. A. Sudiani and N. P. A. Darmayanti, "Pengaruh Profitabilitas, Likuiditas, Pertumbuhan, dan Investment Opportunity Set Terhadap Nilai Perusahaan," E-Jurnal Manaj. Unud, vol. 5, no. 7, pp. 4545-4547, 2016.

A. N. D. A. Putra and P. V. Lestari, "Pengaruh Kebijakan Dividen, Likuiditas, Profitabilitas dan Ukuran Perusahaan Terhadap Nilai Perusahaan," E-Jurnal Manaj. Unud, vol. 5, no. 7, pp. 4044-4070, 2016.

D. R. Wulandari, "Pengaruh Profitabilitas, Operating Leverage, Likuiditas Terhadap Nilai Perusahaan Dengan Struktur Modal Sebagai Intervening," Account. Anal. J., vol. 2, no. 4, pp. 455-463, 2013.

S. Lumoly, S. Murni, and V. N. Untu, "Pengaruh Likuiditas, Ukuran Perusahaan dan Profitabilitas Terhadap Nilai Perusahaan (Studi pada Perusahaan Logam dan Sejenisnya yang Terdaftar di Bursa Efek Indonesia)," J. EMBA, vol. 6, no. 3, pp. 1108-1117, 2018.
K. N. Mery, Zulbahridar, and P. Kurnia, "Pengaruh Likuiditas, Leverage dan Profitabilitas Terhadap Nilai Perusahaan dengan Kebijakan Dividen Sebagai Variabel Moderasi Pada Perusahaan Pertambangan yang Terdaftar di Bursa Efek Indonesia Tahun 2011-2014," J. Online Mhs. Fak. Ekon. Univ. Riau, vol. 4, no. 1, pp. 2000-2014, 2017.

M. Febrianti, "Faktor-Faktor yang Mempengaruhi Nilai Perusahaan Pada Industri Pertambangan di Bursa Efek Indonesia," J. Bisnis dan Akunt., vol. 14, no. 2, pp. 141-156, 2012.

A. Adetunji, O. State, A. Akinyemi, I. O. State, O. Rasheed, and I. O. State, "Financial leverage and firms' value : a study of selected firms in nigeria," Eur. J. Res. Reflect. Manag. Sci., vol. 4, no. 1, pp. 14-32, 2016.

I. S. Ferina, R. Tjandrakirana, and I. Ismail, "Pengaruh Kebijakan Dividen, Kebijakan Hutang, dan Profitabilitas Terhadap Nilai Perusahaan (Studi Pada Perusahaan Pertambangan yang terdaftar di BEI Periode 2009-2013)," J. Akuntanika, vol. 1, no. 2, pp. 52-66, 2015.

A. Rodoni and H. Ali, Manajemen Keuangan Modern. Jakarta: Mitra Wacana Media, 2014.

I. M. Sudana, Manajemen Keuangan Perusahaan. Jakarta: Penerbit Erlangga, 2011.

E. Y. Lestari, "Pengaruh Likuiditas, Leverage, dan Profitabilitas Terhadap Nilai Perusahaan Dengan Kebijakan Dividen Sebagai Variabel Moderating (Studi Pada Perusahaan Manufaktur Yang Terdaftar Di BEI Tahun 2011 2014)," Universitas Muhammadiyah Yogyakarta, 2017.

W. R. Murhadi, Analisis Laporan Keuangan Proyeksi dan Valuasi Saham. Jakarta: Salemba Empat, 2013.

I. Dunanti, D. Lie, and I. A. Efendi, 
"Pengaruh Likuiditas dan Profitabilitas Terhadap Nilai Perusahaan Pada Perusahaan Sub Sektor Property dan Real Estate yang Terdaftar Di Bursa Efek Indonesia," J. Mak., vol. 3, no. 2, 2017.

W. T. Harrison Jr, C. T. Horngren, C. W. Thomas, and T. Suwardy, Akuntansi Keuangan Internasional, Edisi $8 \mathrm{Ji}$. Jakarta : Penerbit Erlangga, 2011.

U. N. Rahmawati, "Pengaruh Likuiditas, Leverage, Dan Profitabilitas Terhadap Nilai Perushaan dengan Kebijakan Dividen Sebagai Variabel Moderasi (Studi Pada Perusahaan Manufaktur yang Terdaftar di BEI)," UIN Maulana Malik Ibrahim Malang, 2017.

P. D. Martini and I. B. Riharjo, "Pengaruh Kebijakan Utang dan Profitabilitas Terhadap Nilai Perusahaan: Kebijakan Dividen Sebagai Variabel Pemoderasi," J. Ilmu dan Ris. Akunt., vol. 3, no. 2, 2014.

Sugiyono, Metode Penelitian Bisnis (Pendekatan Kualitatif, Kuantitatif, dan $R \& D)$. Bandung : ALFABETA, 2012.

I. Ghozali, Aplikasi Analisis Multivariate dengan Program SPSS. Semarang: Badan Penerbit Universitas Diponegoro., 2012.

I. Ghozali, Aplikasi Analisis Multivariate dengan Program IBM SPSS 23, Edisi kede. Semarang: Badan Penerbit Universitas Diponegoro, 2013.

B. I. Wijaya and I. N. P. Sedana, "Pengaruh Profitabilitas Terhadap Nilai Perusahaan (Kebijakan Dividen dan Kesempatan Investasi Sebagai Variabel Mediasi)," EJurnal Manaj. Unud, vol. 4, no. 12, pp. 4477-4500, 2015.

I. Fahmi, Analisis Laporan Keuangan. Lampulo : ALFABETA, 2011. 